\title{
Poverty and precarious employment: the case of Rohingya refugee construction workers in Peninsular Malaysia
}

\author{
Melati Nungsari (i) ${ }^{1 凶}$, Sam Flanders ${ }^{1} \&$ Hui-Yin Chuah $^{1}$
}

How do refugees economically cope in host countries where they have no legal right to work? Most Southeast Asian countries have not ratified the 1951 United Nations Refugee Convention. This implies that many refugees in this region do not enjoy any protection from the law, do not possess the legal right to work, and often resort to participation in dirty, dangerous, and demeaning jobs in order to make ends meet. In this paper, we study Rohingya refugees working as construction workers in the informal economy in Peninsular Malaysia by employing a mixed methods methodology. Specifically, we utilize micro-level survey data collected from a representative population of 314 Rohingya refugee workers in the construction industry, as well as in-depth interviews conducted with a subset of 77 of the survey respondents. Using the survey data, we first provide an overview of the social and economic lives of our respondents by summarizing key variables such as demographics, integration measures, and healthcare access. We then utilize regression analysis to understand the relationships between these variables. The key quantitative finding is that Rohingya refugees in the construction industry earn significantly above minimum wage in Malaysia (albeit less than their legal counterparts), and significantly more than their earnings prior to arriving in Malaysia. This is true even after adjusting for purchasing power. We then conduct a thematic analysis on the qualitative data obtained through the interviews to understand the dimensions of employment for the respondents. We find that although the construction industry in Peninsular Malaysia has provided Rohingya refugees with the means to escape poverty, they still face a tremendous amount of precarity and uncertainty in their lives. 


\section{Introduction}

he United Nations High Commissioner for Refugees (UNHCR) champions the following three durable solutions for refugees: voluntary repatriation, resettlement to a third country, and local integration (UNHCR, 2016). In past refugee crises, international responses have often focused on large scale resettlement or repatriation. For instance, the International Refugee Organization, established post World War II, repatriated or resettled about 1 million people who were forcibly displaced by the war within 7 years of operation starting 1946. (United Nations, 1946). Additionally, in response to the Indochina Refugee Crisis, there were more than 1.8 million people who were either repatriated or resettled from their countries of first-asylum between 1975 and 1997 (UNHCR, 2000).

Like many countries in the Southeast Asian region, Malaysia has not ratified the 1951 Refugee Convention or the 1967 Protocol (Stange et al., 2019). This implies that refugees in Malaysia are not legally recognized and have restricted access to public resources such as public healthcare and education (Lego, 2018; Nungsari et al., 2020). In the absence of a formal legal framework, refugees are denied the legal rights to work, and often resort to participation in dirty, dangerous, and demeaning jobs in order to make ends meet (Buscher and Heller, 2010; Sullivan, 2016; Salim, 2019; Ghazali et al., 2020a). Although refugees in Malaysia do not legally have any rights, it is important to note that they are often tolerated and spared prosecution by Malaysian law enforcement (Yesmin, 2016). Access to education is also possible through community schools funded by the UNHCR or local NGOs (Bailey and İnanç, 2018). Refugees can also visit public hospitals and clinics but must pay consultation fees of 40 times the local rate, which is often not feasible (Chuah et al., 2018). Additionally, they do not live in camps and are able to move around the country relatively freely (Nah, 2010). The formal stance of the Malaysian government is that Malaysia serves as an intermediate destination for refugees-the country of first-asylum-with the understanding that refugees will eventually be resettled to other countries such as Australia, the United Kingdom, and the United States (Alhadjri, 2020).

However, resettlement rates have plummeted in the recent years despite the significant rise in the numbers of refugees globally. As traditional resettlement destinations close their doors to refugees, asylum-seekers and refugees have increasingly ended up in limbo in countries that were once brief, intermediate stops in their resettlement journey (Milner, 2014; Hoffstaedter and Perrodin, 2019). These intermediate countries typically do not provide formal status for refugees, forcing them to live on the margins of society (Kuhlman, 1991; Crisp, 2003). The more than 100,000 Rohingya refugees residing informally in Malaysia are one such group (UNHCR Malaysia, 2020). According to UNHCR (2020a, 2020b), only $2 \%$ of the total refugee population in Malaysia were resettled in 2018. The problem is further exacerbated by ongoing conflicts in home countries, making voluntary repatriation impossible (Warner, 1994; Chimni, 2004). Many refugees end up living in Malaysia for decades, if not for the rest of their lives (Letchamanan, 2013). This corresponds to the UNHCR global report in 2018, which stated that $78 \%$ of refugees are in protracted situations (UNHCR, 2019a). According to the same report, the decrease in resettlement worldwide is a serious problem for developing countries, since $84 \%$ of the world's displaced people are in developing countries with limited resources in bringing forward sustainable solutions for refugees who reside within their borders.

Therefore, it is important to understand how refugees earn their livelihood in countries like Malaysia. We find that, although the construction industry in Peninsular Malaysia has provided Rohingya refugees with the means to escape poverty, they still face a tremendous amount of precarity and uncertainty in their lives. To study this issue, we use a unique dataset-surveys and interviews from 314 Rohingya refugees in the construction industry. The analysis conducted in the paper is divided as follows. We first provide an overview of our population by summarizing variables relevant to their economic life-this includes their demographics, integration with the local community, and access to healthcare. We then study their income levels in Malaysia and assess whether or not they are currently in poverty according to the National Poverty Line Income (PLI) definition at time of data collection (2018), which was RM $980(\sim 230)$ per household (Syed Jaafar, 2020) ${ }^{1}$. We also compare their current income levels with their previous income levels prior to migrating to Malaysia (i.e., in Myanmar). Thirdly and finally, we randomly select a subset of qualitative interview data from our respondents and focus on questions relating to their work. We then use thematic analysis to derive the dimensions of employment facing our respondents (Daly et al., 1997; Braun and Clarke, 2006; Joffe, 2011). It is important to note that some problems due to lack of or inadequate employment can be mitigated through the provision of informal social safety nets through social networks (Smith, 2012; Wake and Cheung, 2016) -for example, refugees can gain access to shelter, as well as advice and information for job opportunities through their social networks. However, due to the extreme vulnerability of the Rohingya as an ethnic group (Ibrahim, 2016), it is unlikely that social safety nets will be able to overcome all problems faced by members of the community.

The paper proceeds as follows: Section "Background" provides the background for the study, Section "Data collection and methodology" presents the data collection process and methodology, Section "Analysis and findings" presents our analyses and findings, Section "Conclusion" concludes, and Section "References" presents the references.

\section{Background}

The movement of populations across geographical borders has been an integral part of human history. Migration is a multifaceted process that is driven by a complex set of factors. Mobility decision by individuals or households often involve an interplay of choice and necessity that are shaped by the structural context within which the decisions are made (Massey et al., 1993; Richmond, 1993; Turton, 2003; Castles, 2010). While there have been several theoretical advance in the migration literature, our understanding of the complexity of human mobility or immobility remains incomplete (Massey et al., 1993; Arango, 2000; Castles, 2010). One of the key research areas in migration focuses on the nexus between migration and development-which examines the impact of migration on development, poverty and inequality (de Haan, 1999; de Haas, 2010). When considering forced migrants and refugees, Jacobsen (2014) argues that "the study of livelihoods of forced migrants straddles the poverty alleviation literature and the literature on undocumented migration, since many refugees live without formal status in host countries". Thus, to understand the economic life of refugees, one must seriously consider the interplay between poverty and migration.

The debate on whether or not migration reduces poverty remains inconclusive. On one hand, Adams and Page (2005), Sabates-Wheeler et al. (2008), and Skeldon (2003) find that migration improves the livelihood of the migrants and also contributes to poverty reduction in the country of origin through remittances and knowledge transfers. For example, Huennekes (2018) studied remittances among Rohingya refugees in Malaysia 
and highlighted the importance of remittances as not just financial support but also a way to maintain family ties, as well as the emotional burden that is attached to this practice. Nord (1998) and Chiswick (1999), on the other hand, suggest that the selectivity of migration has excluded those who are chronically or extremely poor from pursuing migration as a strategy to escape poverty. In other words, people who can afford to migrate have better social mobility in improving their life while those of the lowest income group are more likely to remain trapped in their home countries in extreme poverty.

The relationship between migration and poverty is further complicated by causal ambiguity-specifically, because poverty can be both the cause and consequence of migration (Kothari, 2002). The term "poverty" itself is multifaceted and can be measured in a variety of ways (Wagle, 2002). In their similar paper on the definition and measurement of poverty, Hagenaars and de Vos (1988) posit that all definitions of poverty can fit into one of the following categories: poverty as an objectively defined, absolute minimum, poverty as having less than others in society, and poverty as feelings of not having enough to get along with day-to-day life. In our paper, we operationalize "poverty" by employing the first definition in Hagenaars and de Vos (1988) by defining a household as impoverished if they fail to meet the Malaysian Poverty Line Income.

The Rohingya in Malaysia. According to UNHCR Population Statistics, Malaysia hosted refugees from $>26$ countries in 2018. Out of this population, the Rohingya people of Myanmar form the majority. According to an internal report shared with us by UNHCR Malaysia, as of February 2018, the Rohingya people constituted roughly $44 \%$ of the total refugee and asylum-seeker population registered by UNHCR Malaysia, with about 69,000 individuals registered. According to the same report, almost half (47\%) of the working Rohingya population worked in the construction sector.

The Rohingya are a predominantly Muslim ethnic group from Buddhist-majority Myanmar, most of whom hail from the western coastal state of Rakhine. The debate on the history of the Rohingya in Myanmar is highly contested and politically fraught (Ibrahim, 2016; Kyaw, 2017). The general facts are as follows. Myanmar was occupied by the British from 1824-1948, during which it brought laborers from India and Bangladesh into Burma. After independence from the British, the Burmese government viewed these migrations as illegal - many Burmese individuals considered the Rohingya to be Bengali and not Burmese, despite the fact that the Rohingya people's presence in the state of Rakhine can be traced as far back to tenth century (Ibrahim, 2016). ${ }^{2}$ This "outsider" discourse was further perpetuated through state instruments like the 1974 Constitution in Myanmar, which issued Rohingyas with foreigner identity cards instead of national registration cards. Later, the 1982 Myanmar Citizenship Law rendered the Rohingya people stateless as they were not recognized as one of Myanmar's 135 ethnic groups. According to Amnesty International (2017), constant violent attacks against Rohingya have led to multiple waves of displacement in 1978, 1991-1992 and the most recent one in 2017, causing hundreds of thousands of Rohingya to flee to neighboring countries such as Bangladesh, Malaysia, India, and Pakistan.

Refugees and asylum-seekers in Malaysia are primarily urban dwellers who stay in urban settlements instead of designated refugee camps like many other host countries, such as Thailand (UNHCR, 2019b). Refugees in Malaysia often suffer economically due to the absence of formal opportunities to earn a living in Malaysia (Smith, 2012; Wake and Cheung, 2016; Ghazali et al., 2020b). The informal economy provides a way for refugees and asylum-seekers to earn an income.

While it is difficult to define and assess the size of informal economics worldwide, experts have estimated that the informal economy comprises an average of $31.5 \%$ of total GDP for 158 countries over the period of 2004-2015. The estimation is based on the definition used by (Medina and Schneider, 2018, p.73), which covers mostly legal economic and productive activities hidden from official authorities. The same study estimates that the average size of informal economy over the period of $2004-2015$ is about $31.5 \%$ of the national GDP despite a trend of shrinking from $30.6 \%$ to $26.1 \%$ over the years. Malaysia in particular has a booming informal economy-one estimate states that informal employment constitutes $39 \%$ of total employment in Malaysia in 2017 (Schmillen et al., 2019).

\section{Data collection and methodology}

This research is based on primary sources:

1. A survey of 314 Rohingya individuals who self-identified as having worked in construction in the past year at UNHCR headquarters in Kuala Lumpur. This survey was conducted for three months in June, July, and August of 2018, and contained both close-ended survey questions, as well as semi-structured interview questions.

2. A focus group with six Rohingya community leaders in May 2018 who have experience working in the construction industry.

3. In-depth interviews of eight Rohingya individuals, comprising of four females and four males.

Source 1 is the most important as it contains the most observations and is most representative of the overall population, since it was obtained by interviewing refugees who self-identified as Rohingya were waiting at the UNHCR Malaysia office for either (1) renewal of their UNHCR card, (2) a registration interview, or (3) a resettlement interview. The survey was conducted by a research team consisting of three full-time research assistants, six UNHCR volunteers, and one UNHCR intern. The research team underwent training prior to conducting the surveys and were rebriefed every week after the principal investigators reviewed the survey data collected in the previous week. This was for quality assurance and to correct any systematic mistakes that the surveyors were making so that they were not repeated.

The survey itself had 49 questions, some of which had multiple parts. The survey included nine open-ended questions where answers were audio-recorded and transcribed. Respondents were first read a consent preamble describing the nature and purpose of the survey and their prerogative to decline the survey in light of this information-though none did. Respondents were paid a small cash amount at the end of the survey (RM 10, USD \$ 2.50) for their time. The survey was conducted in Bahasa Malaysia or Rohingya, depending on the respondent. If the survey participant did not understand Bahasa Malaysia, a Rohingya interpreter was utilized. All quotations from interview data were transcribed and translated verbatim and are presented here in English for ease of reading. The survey typically took about $30 \mathrm{~min}$ to complete, although it ranged from $18 \mathrm{~min}$ to $1 \mathrm{~h}$ and $20 \mathrm{~min}$. The complete survey can be made available to the reader upon request.

When working with vulnerable populations such as refugees, it is important to note the power asymmetries in the research process (Elwood and Martin, 2000; Briggs, 2001; Anyan, 2013). We fully acknowledged this from the start and addressed it in several ways. The first was by partnering with a trusted partyUNHCR Malaysia-throughout the process. The second was devoting a significant amount of time before the start of the data 
collection to providing sensitivity and background training to every member of the research team. The third was to ensure that consent was obtained after a thorough explanation of the study, and what was required of the respondents (including, most importantly, their agency in declining to participate). We worked with the Registration Unit at UNHCR Malaysia to conduct consecutive sampling of survey respondents-that is, on the days that we came in to survey (2-5 days a week), all self-identified Rohingya construction workers who came in to renew their UNHCR cards or undergo their registration interview and were willing to participate in the survey were referred to our research team. In addition to the referrals, members of our research team also approached individuals who were waiting in the waiting area for either their card renewal, their registration interview, or resettlement interview. The research team then asked whether they identified as a Rohingya person, and whether they had worked in construction in the past year. If the answers to the two questions were "yes", the research team then asked for their consent to be surveyed. The research team reported an $80 \%$ success rate in obtaining survey respondents this way, with most of the $20 \%$ who refused to be surveyed stating that they did not want to be interviewed because they were worried that they would miss their spot in the interview queue. However, since the conversion rate from referrals to actually being seen and interviewed by the research team was about $100 \%$, most of the respondents who declined to be interviewed due to fears of missing their spots in the interview queue were eventually interviewed later in the day. Consequently, the observations in Source 1, though only from a sample of 314 individuals, are likely to be highly representative of the overall registered population of Rohingya working in construction, with the proviso that it may be slightly overrepresentative of more recent arrivals. The primary differences between our sample and the broader population are that our sample excludes children, has few older respondents, and most importantly, has no women. A random selection of the interview questions from Source 1 was analyzed using thematic content analysis (Braun and Clarke, 2006) in Section "Analysis and findings".

To help guide the building of the survey questions used in Source 1, we first conducted a focus group with six Rohingya community leaders who have had experience working in the construction industry (Source 2). This focus group was done in May 2018 and was led by two of the authors in Bahasa Malaysia with several UNHCR representatives, and some members of the research team present. This was a loosely guided conversation on the Rohingya experience in construction. The conversation was 2hour long. The community leaders were either leaders of community organizations or individuals who were identified as "successful construction workers" in the community. Demographically, they were very different than the survey respondents in Source 1. The average number of years in Malaysia for the focus group was 17.3 years, with a minimum of 6 years and maximum of 28 years. The group was also noticeably older and more experienced-the average age in the group was 40.7 years, with a minimum of 30 years and a maximum of 48 years. They also reported higher daily salaries-most had worked as subcontractors in the construction industry-that went up to RM 200 per day. Even though the focus group participants were not representative of the Rohingya construction worker population at large, they did highlight some themes that we explored and affirmed in the surveys done afterwards.

Source 3 is data collected in parallel study in which we conducted in-depth interviews with refugees and asylum-seekers from different ethnic groups and nationalities to learn more about their lives in Malaysia. Eight Rohingya interviewees from diverse backgrounds in these interviews provided insights included in this paper. These semi-structured interviews centered around issues on their displacement, well-being, livelihoods, security concerns, integration, as well as future plans, if any. Among this small sample, some respondents were involved in advocacy and volunteering work in the community and were proficient in English. The other respondents were housewives, retirees, and teachers at community schools.

Ethics statement. The data in this study were collected in accordance with the guidelines set our institution's Institutional Review Board. Every participant was briefed on the purpose of the study in a language that they understood. This briefing included, among other topics, their right to withdraw from the interview or survey if they felt uncomfortable. Afterwards, written or informed consent was obtained from each participant.

\section{Analysis and findings}

An overview of Rohingya construction workers in Peninsular Malaysia. We will begin by describing the demographics of construction workers. These workers are young: the interquartile range for our sample is 22 to 30, as depicted in Fig. 1. To some extent, this can be attributed to the youthful profile of the Rohingya population in Malaysia, as described in Section "Background", but also reflects the strenuous nature of construction work.

The interquartile range for years since arrival is four to six, reflecting major exoduses in the Rohingya crisis in Myanmar due to the escalated violence between Muslims and Buddhists since 2012 (Amnesty International, 2017), while likely undercounting recent arrivals-refugees do not instantly apply for, much less receive, interviews with UNHCR when first arriving in Malaysia. The distribution of time since arrival in Malaysia is depicted in Fig. 2.

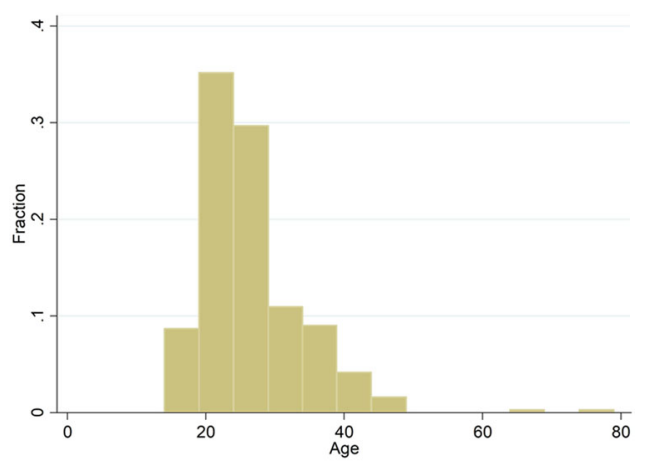

Fig. 1 Distribution of age among respondents. Respondents distribution by age (year).

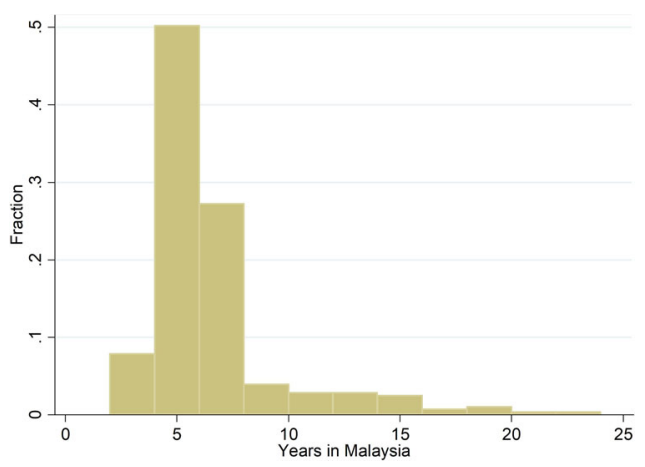

Fig. 2 Distribution of time since arrival in Malaysia. Respondents distribution by number of years since arrival in Malaysia (year). 


\begin{tabular}{|lccc|}
\hline Table 1 Demographics. & \multicolumn{3}{l|}{ 年 } \\
Education & Percentage & $\begin{array}{l}\text { 95\% confidence } \\
\text { interval }\end{array}$ \\
\hline None & $58.90 \%$ & $53.30 \%$ & $64.30 \%$ \\
Less than elementary & $26.90 \%$ & $22.20 \%$ & $32.10 \%$ \\
Elementary & $9.10 \%$ & $6.30 \%$ & $12.80 \%$ \\
Less than high school & $3.60 \%$ & $2.00 \%$ & $6.30 \%$ \\
High school & $1.00 \%$ & $0.30 \%$ & $3.00 \%$ \\
Some college & $0.30 \%$ & $0.00 \%$ & $2.30 \%$ \\
College degree & $0.30 \%$ & $0.00 \%$ & $2.30 \%$ \\
Marital status & & & \\
Unmarried & $58.40 \%$ & $52.80 \%$ & $63.80 \%$ \\
Spouse abroad & $20.00 \%$ & $15.90 \%$ & $24.90 \%$ \\
Spouse in Malaysia & $21.60 \%$ & $17.40 \%$ & $26.60 \%$ \\
\hline
\end{tabular}

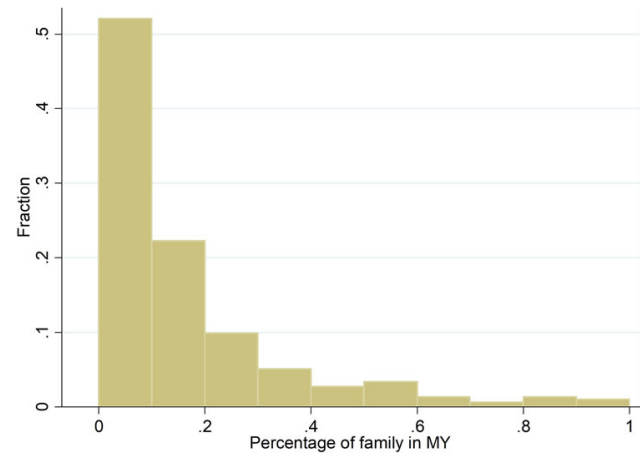

Fig. 3 Distribution of percentage of family in Malaysia. Respondents distribution by percentage of family in Malaysia, defined as the number of living parents, siblings, children, and spouses in Malaysia divided by the number of livin parents, siblings, children, and spouses.

This matches the findings in the report by UNHCR (2020b), which refers to at least 25,000 refugees from Myanmar living in exile for $>5$ consecutive years. Many respondents in our study expressed the feeling of being stuck in limbo as it is both not safe for them to return home and their chances of being resettled to a third country were dwindling.

Educational attainment is very low for Rohingya working in construction, as depicted in Table 1 . Most have no education whatsoever, and most of the remainder have less than an elementary education. This reflects the Rohingya's legal exclusion from formal education in Myanmar (Lewa, 2009; US Department of State, 2019). Even those who have been in Malaysia since childhood have limited access to education. They are excluded from public schooling due to their informal status, and while some attend NGO run schools, most receive only a few years of schooling before leaving to work due to financial difficulties (Letchamanan, 2013).

While there is a large Rohingya population in Malaysia, most of the Rohingya abroad are in other countries. According to a recent report, 600,000 Rohingya remain in Rakhine state (United Nations, 2019). Bangladesh remains the largest host of Rohingya refugees, with $>800,00$ Rohingya residing within its borders (UNHCR, 2019c). Thus, most individuals in our sample have families fragmented across multiple countries. In fact, nearly half have no relatives in Malaysia at all, while only about $5 \%$ have more than half family in Malaysia, as depicted in Fig. 3. On average, a Rohingya working in construction remit about a quarter of their income to other countries. Many respondents spoke of the importance of remittances to family members who

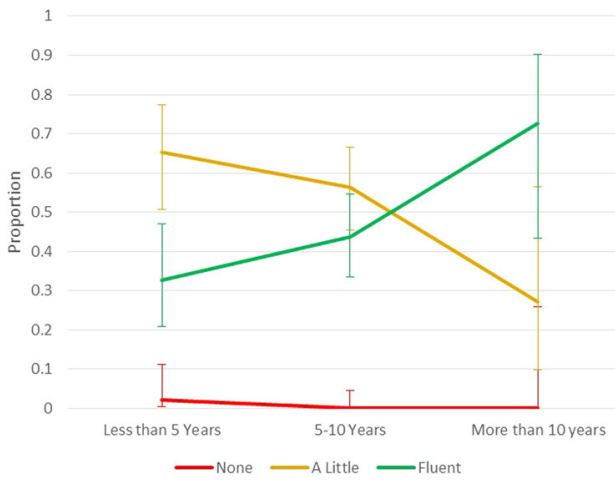

Fig. 4 Spoken Malay language skills for respondents who arrived aged 18 or less, by time in Malaysia. Vertical bars represent $95 \%$ confidence intervals on population proportions.

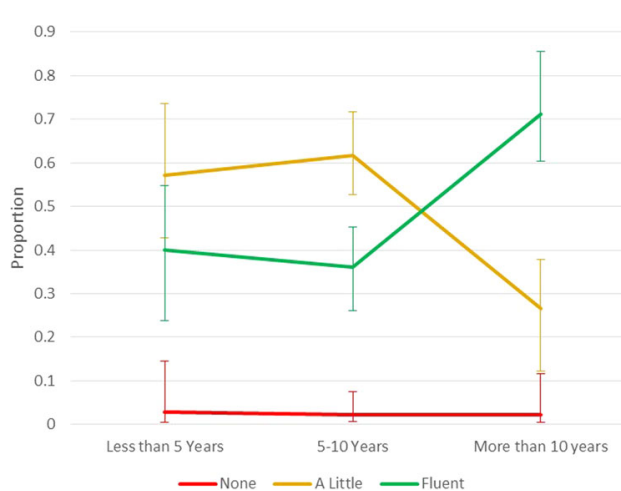

Fig. 5 Spoken Malay language skills for respondents who arrived aged 19 or older, by time in Malaysia. Vertical bars represent $95 \%$ confidence intervals on population proportions.

are not in Malaysia. For some respondents who have wives and children still living in Myanmar or Bangladesh, remittances are the sole means by which breadwinners provide for their nuclear families as remarked by one of the community leaders below,

"We need higher pay since we have to send back money to our village. We must work hard. We have our relatives at home in Myanmar. We have to support them and our family here too. We have to support both families".

Despite the youthful profile of our sample, many are married, as can be seen in Table 1. However, even spouses are often separated. More than half of married respondents have a spouse living abroad. Every respondent was male, and every spouse was female.

According to the literature on migration, one obvious metric of integration is command of local language skills (Alba and Nee, 1997; Chiswick and Miller, 2001; Remennick, 2003). Stratifying the sample by age at arrival and years of residing in Malaysia, we see in Fig. 4 that those who arrive aged 18 or younger develop significant Malay language skills even in the first four years, with almost all speaking at least a little Malay and about a third speaking it fluently.

We find that cohorts that have been in Malaysia longer have consistently better Malay skills, with about three quarters of young arrivals who have been in the country for more than a decade being fluent in the language.

Those who arrive as adults aged 19 or older have similar levels of fluency as the cohorts that have arrived in the past four years and $>10$ years ago, but the middle cohort appears less fluent, as seen in Fig. 5. This may be an artifact of the small sample size or 


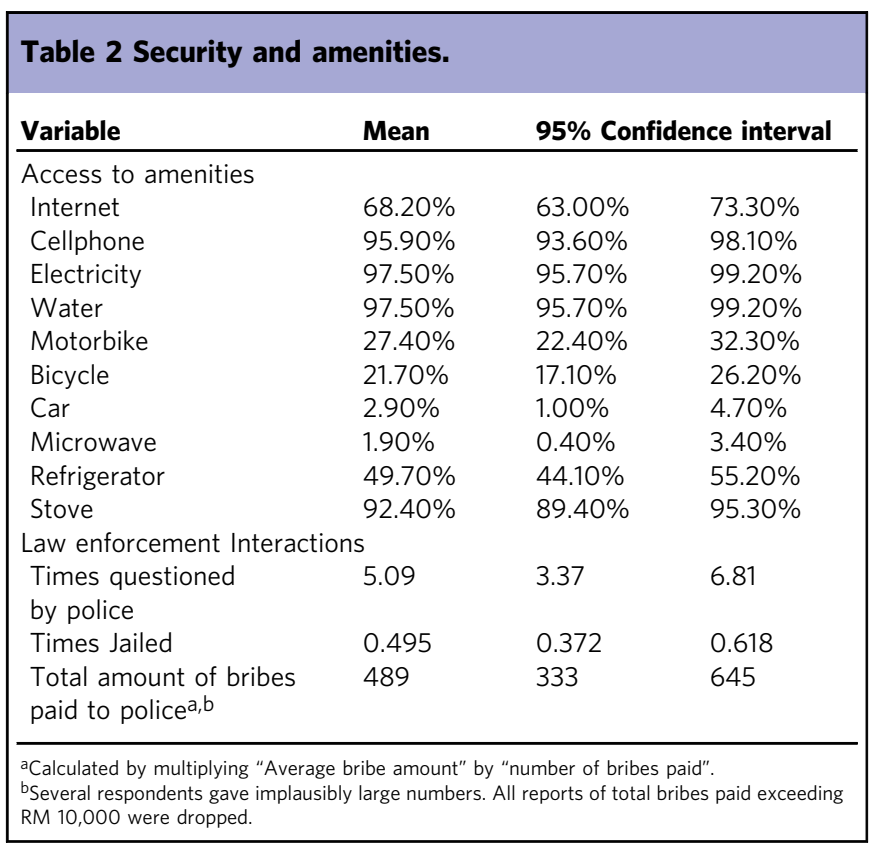

could reflect underlying differences between the cohorts. Regardless, the cohort that has been in the country for a decade or more is highly fluent.

While income can be an important index of precarity and marginalization, it is far from dispositive in and of itself. Refugees in Malaysia occupy a legal gray area: they are informally tolerated, and police often treat their documentation from UNHCR as valid, but they have no formal status in Malaysia and can be arrested on immigration charges at an officer's discretion (Kaur, 2007; Buscher and Heller, 2010). From our in-depth interviews, there are also reported cases where law enforcement officers do not recognize their UNHCR cards:

"Some more those people who got caught, they complain to me. If this card is original from UNHCR, it's not fake card, or it's not paper, ..., the immigration just break it in front of them (and questions them). Now where is your card?"

Table 2 shows that our sample is frequently questioned by the police $\rightarrow 5$ times since their arrival in Malaysia on average. Only about $30 \%$ have never been questioned. That works out to about once a year on average. About one third have been jailed in Malaysia, and almost $10 \%$ have been jailed more than once. To avoid jail, it is common for Rohingya refugees to pay bribes to the police, either in cash or in-kind payments, such as food, as illustrated below.

"If they want money, just pay them up. If they are okay, you'll escape. If not, you'll get a fine. Some are very understanding, you gave them "money for coffee", they'll let you go. If not, the station you'll go. Your motor will get confiscated, you have to pay up to the court. And then, you'll be free".

"Sometimes, those with cards have no problems. Those without will be arrested. But sometimes those with cards are held and kept for hours. If we get them drinks and make them happy they let us go. That is always the case".

About one quarter of respondents paid RM 300 or more over their time in Malaysia, and the average was almost RM 500, reflecting payouts of over RM 1000 total from a minority of respondents.
Table 3 Correlates of jailing.

\begin{tabular}{|c|c|c|}
\hline & (1) Jail & (2) Jail \\
\hline Years in Malaysia & $0.0114(0.13)$ & $0.0225(0.24)$ \\
\hline Years in MY squared & 0.00566 (1.37) & $0.00482(1.16)$ \\
\hline $\begin{array}{l}\text { Age at arrival in } \\
\text { Malaysia }\end{array}$ & $0.142^{\star \star}(2.86)$ & $0.113^{\star}(2.29)$ \\
\hline $\begin{array}{l}\text { Age at arrival in } \\
\text { Malaysia squared }\end{array}$ & $-0.003^{\star \star}(-3.02)$ & $-0.00235^{\star}(-2.46)$ \\
\hline Own a cellphone & $-1.291(-1.3)$ & \\
\hline Daily wage (RM) & $-0.00274(-0.67)$ & $\begin{array}{l}-0.0000978 \\
(-0.26)\end{array}$ \\
\hline Education level & $-0.0805(-1.9)$ & $-0.0992^{\star}(-2.16)$ \\
\hline Speak a little Malay & $0.574(1.24)$ & $0.308(0.94)$ \\
\hline Fluent in Malay & $0.389(0.89)$ & $0.143(0.45)$ \\
\hline Constant & $-0.474(-0.42)$ & $-1.29(-1.63)$ \\
\hline Observations & 249 & 249 \\
\hline \multicolumn{3}{|c|}{$\begin{array}{l}\text { The variable refers to education level from Table } 1 \text { encoded numerically, starting at } 0 \text { and } \\
\text { incrementing } 1 \text { for each level up to } 6 \text { for "College Degree". } \\
t \text { statistics in parentheses. } \\
{ }^{\star} p<0.05,{ }^{\star \star} p<0.01,{ }^{\star \star \star} p<0.001 \text {. }\end{array}$} \\
\hline
\end{tabular}

Table 3 provides two simple ordinary least-squares (OLS) regressions predicting the number of times jailed. The first includes the basic covariates used in Table 3 , plus wage ${ }^{3}$, while the second includes cellphone access. In terms of effect magnitude, the strongest determinant of jailing is cellphone access - those who do not have a cellphone have been jailed far more frequently. However, few respondents do not have a cellphone, so the result is not statistically significant. This may reflect the fact that owning a cellphone can provide instant access to external help, such as UNHCR officers and NGOs that offer legal services.

"if you are arrested by the immigration there is only one way to come out from the court. They will send to the court first, and the judge will decide how many months you need to go, and if you have your own lawyer for the person who is arrested then you can bring them out from there".

Education and Malay language skills, by contrast, seem to make little difference, although it has a small, barely significant negative association with jailing in specification (2). This suggests that the possibilities for refugees to talk their way out of arrest are limited. If most respondents have not been jailed, and a refugee's own communication skills are not especially pivotal, it may be that the outcome of police interactions hinge primarily on the attitude of the officer, given the enormous discretion they wield. Wages do not seem to have a strong relationship with jailing, either. This could be an artifact of the small sample size, or it could be that officers accept bribes based on ability to pay as illustrated in the quotes below from some of the interviewees from Source 3.

"So, any time the police can arrest us, any time the police... immigration...yeah! So it depend on people, depend on police... depend on immigration. If they are nice, if they have mercy on their mind, they let us to go. If they don't, they can detain in the immigration camp, they send to us to the prison no problems. No one will investigate. Where we will go to complain?!"

"... if you arrested by the police there is always a way to come back unless you have commit a crime they will take you away because we don't have a documentation. If you want to set it on the street it can be 100 or 200 (ringgit). If 
they bring us to the police station it goes until 2000 or $3000 "$.

Age at arrival is statistically significant in both specifications and yields an inverted $U$ relationship between jailing and agethose who arrive in childhood or in middle-age or later are less likely to be arrested. In the former case, it is likely because they develop the skills to avoid interactions with the police; in the latter, because they are too old to attract attention. Men who arrive around 25 are at the greatest risk.

While our sample faces a substantial risk of incarceration, they do generally have access to basic amenities, as seen in Table 2. Nearly all have access to a cellphone, electricity, running water, and a stove. Most have internet access. Technology like mobile phone and internet is almost like a necessity for them to sustain their life according to the observation by one of the interviewees who is an active policy advocate below. About half have a refrigerator. A sizable minority have a vehicle. Given the statement "I have enough food to eat every day", $<10 \%$ disagreed or strongly disagreed.

"Last time they don't know how to use phone. Now they know how to use Facebook. They doing video calls to their country. That's the most. They're using messenger to call their families from the video call and even WhatsApp. They are also using WhatsApp to make groups for their family member. Inform each other in what is happening. Mostly".

Finally, while the refugees in our sample typically have very modest housing, they are not generally homeless or crowded into tiny dwellings. The median number of rooms per occupant is 2.5 in our sample's dwellings. Rent takes up only a modest portion of respondent income-for those who pay rent, the median is RM 300 per month, compared to a median income of about RM 1400, as depicted in Fig. 6. About a third pay no rent, receiving board as payment-in-kind from their employer.

More than half of respondents agreed or strongly agreed that they had adequate access to healthcare, but about a third disagreed or strongly disagreed. This heterogeneity may relate to the intermittent need for care among young people-the limitations of their access to healthcare may not be apparent until they need significant treatment, so those who have not had reason to pursue care may have a more positive opinion. This could also link to the positive perception among refugees and asylum-seekers on the healthcare system in Malaysia. A study on Malaysian health system responses to the needs of refugees and asylum-seekers found that many of them commend the high availability and quality of the public health facilities despite complaints about the affordability (Chuah et al., 2019).

The response towards healthcare might also vary by the ability to communicate.

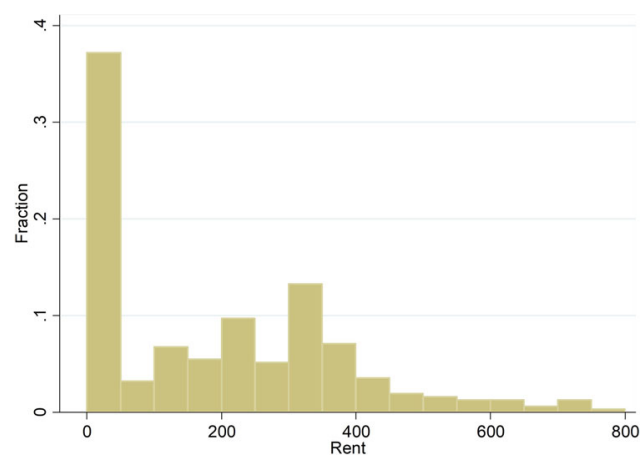

Fig. 6 Distribution of monthly rent (RM). Respondents distribution by monthly rent (RM).
"The way that they treat to the people, is quite different. Because I could speak in English to the doctor, the doctor and the nurse was totally polite with me. Talking politely with me even though I am using UNHCR card. But those other refugees they are also Rohingya but they don't know how to speak a single word of Malay and English and they was totally insulted, totally like when they putting the injection and giving the medicine like they are just throwing the things and pushing and pulling the hand. Not polite to them. And even scolding to the patient".

Income and poverty. The first thing to note on our findings surrounding wages of Rohingya men in construction is how surprisingly high they are. In 2018, the Malaysian minimum wage was RM 1000 per month, which yields a daily wage of as low as RM 38.46 per day for workers with a six-day work week (Federal Government Gazette, 2016). Figure 7 shows that $>90 \%$ of respondents earned more than that-the median daily wage is RM 50. At the same time, these wages are significantly less than what locals make in this industry: even the lowest compensated category of construction worker, "General Construction Worker", made an average of RM 67 per day in 2017, while many specialties made more than RM 100 a day (Construction Industry Development Board, 2018). The distribution of wages is quite narrow.

We then use the Mincer earnings function to explore the how experience (as measured by age) and amount of schooling affect a worker's income (Mincer, 1974). Table 4 provides a minimalist

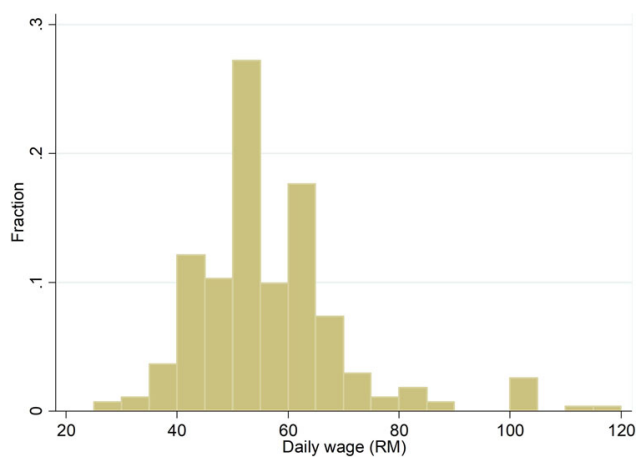

Fig. 7 Distribution of daily wages (RM). Respondents distribution by daily wage (RM).

Table 4 Mincer earnings regressions for daily wages.

\begin{tabular}{|c|c|c|}
\hline & (1) Inwage & (2) Inwage \\
\hline Education level & $0.0149(1.02)$ & $0.0185(1.31)$ \\
\hline $\begin{array}{l}\text { Age at time of } \\
\text { interview }\end{array}$ & $0.0422^{\star \star \star}(5.17)$ & $0.0212(1.52)$ \\
\hline Age squared & $\begin{array}{l}-0.000626^{\star \star \star} \\
(-5.26)\end{array}$ & $-0.000311(-1.36)$ \\
\hline Years in Malaysia & & $0.0495^{\star}(2.28)$ \\
\hline $\begin{array}{l}\text { Years in Malaysia } \\
\text { squared }\end{array}$ & & $-0.00195(-1.67)$ \\
\hline Speak a little Malay & & $-0.152(-1.74)$ \\
\hline Fluent in Malay & & $-0.143(-1.60)$ \\
\hline Constant & $3.332^{\star \star \star}(25.88)$ & $3.581^{\star \star \star}(16.90)$ \\
\hline Observations & 271 & 240 \\
\hline \multicolumn{3}{|c|}{$\begin{array}{l}\text { The variable refers to education level from Table } 1 \text { encoded numerically, starting at } 0 \text { and } \\
\text { incrementing } 1 \text { for each level up to } 6 \text { for "College Degree". } \\
t \text { statistics in parentheses. } \\
{ }^{*} p<0.05,{ }^{\star \star} p<0.01,{ }^{\star \star \star} p<0.001 \text {. }\end{array}$} \\
\hline
\end{tabular}


Mincer earnings function-explaining logged wages in terms of schooling and age in specification (1), and an expanded equation including time since arrival in Malaysia and fluency in specification (2). These results can be interpreted as follows: 100 times the coefficient (non-parenthetic term to the right of the variable name) gives the percentage increase in wages given an increase of one in the variable. Most of the coefficients are not statistically significant in specification (2), largely due to the small sample size. However, the signs of most effects are what would be expected-in both specifications, wages have an inverted $U$ relationship with age-wages increase with age up to a point and then decrease. Tenure in Malaysia increases wages, but this benefit attenuates with time. We would expect education increase wages, and the sign on the coefficient is positive, but it is far from statistically significant in either specification-education seems to provide little benefit on the construction site.

Surprisingly, fluency has a weak but negative relationship with wages - this may be an artifact of the fact that only a handful of respondents had no Malay skills, making it hard to estimate the wage premium for that category. A Rohingya worker who arrived at 20 with basic Malay skills makes a little more than RM 40 a day in specification (2) if they've only just arrived, about RM 50 if they've been in the country for 5 years, and more than RM 55 if they've been in the country for 10 years. A Rohingya worker who arrives at 30 rather than spending 10 years in Malaysia makes a little less than RM 45-the benefits of time in Malaysia, while only marginally statistically significant, may be very economically significant.

Finally, by using the framework of objective measures in Hagenaars and de Vos (1988), we can compare the current income of respondents to their previous income before migrating to Malaysia. We do so by plotting the current income of all respondents in Malaysian Ringgit against their prior income while in Myanmar that has been converted and adjusted, using Purchasing Power Parity, to Malaysian Ringgit. The graph is shown in Fig. 8. As is evident, all but a handful of respondents fall above the 45-degree line, which signifies that most respondents make significantly more income in Malaysia than they did in Myanmar. Thus, if we were to define poverty as "having more than an objectively defined standard", we can conclude that Rohingya construction workers have, indeed, escaped poverty as a result of their migration to Malaysia. However, Wagle (2002) argues that an analysis on poverty that only takes into account economic well-being without considering other dimensions such

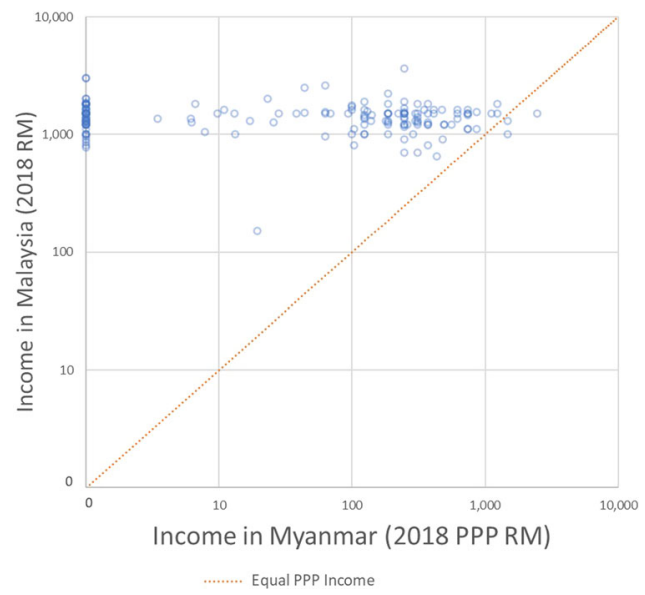

Fig. 8 Income in Malaysia (2018 RM) vs. Income in Myanmar (2018 PPP

RM). Scatter plot of income in Malaysia (2018 RM) and income in Myanmar (2018 PPP RM). as capability (i.e., factors other than income, consumption, and welfare) and social exclusion is inherently flawed. Since the Rohingya in Malaysia are not protected by any legal framework, they are by default socially excluded and incapable of accessing all public resources. Thus, in the subsection below, we take a closer look at their employment as construction workers and try and extract some of the dimensions that govern it, in order to better understand their precariousness.

Dimensions of precarious employment. Scholars differ in their definitions and operationalizations of the term "precarious employment". Kreshpaj et al. (2020) found that precarious employment can generally be categorized according to three dimensions: employment insecurity (which includes contractual relation insecurity, contractual temporariness, contractual underemployment, and employment in multiple jobs/sectors), income inadequacy (relating to low income levels), and lack of rights and protection (which includes lack of unionization, lack of social security, lack of regulatory support, and lack of workplace rights). Quinlan et al. (2001) found that precarious employment is generally associated with a "deterioration in occupational health and safety in terms of injury rates, disease risk, hazard exposures, or worker (and manager) knowledge of occupational health and regulatory responsibilities".

We now turn to the qualitative data to characterize the experience of a Rohingya refugee who is precariously employed. Source 1 included semi-structured interview questions as part of the survey, which allows us to employ thematic analysis on particular questions relevant to precarity and employment. Thematic analysis is a quantitative research method that allows one to extract common themes in the dataset (Braun and Clarke, 2006; Joffe, 2011; Maguire and Delahunt, 2017). In our case, the dataset is answers to 4 questions in Source 1 and our respondents are 77 randomly sampled individuals chosen from the original sample of 314 individuals. Please see Fig. 9 to understand the sampling framework for this portion of analysis.

We coded the qualitative data using the framework in Kreshpaj et al. (2020), which characterizes three dimensions of precarious employment. The three dimensions are employment insecurity, lack of rights and protection, and income inadequacy. Within each dimension, we extracted themes from the interview data (Braun and Clarke, 2006). Under the dimension of employment insecurity, we found the themes of late and lack of salary payments, as well as ambiguous work schedule and periods of employment. Under the dimension of lack of rights and protection, the themes that emerged were extreme heat when

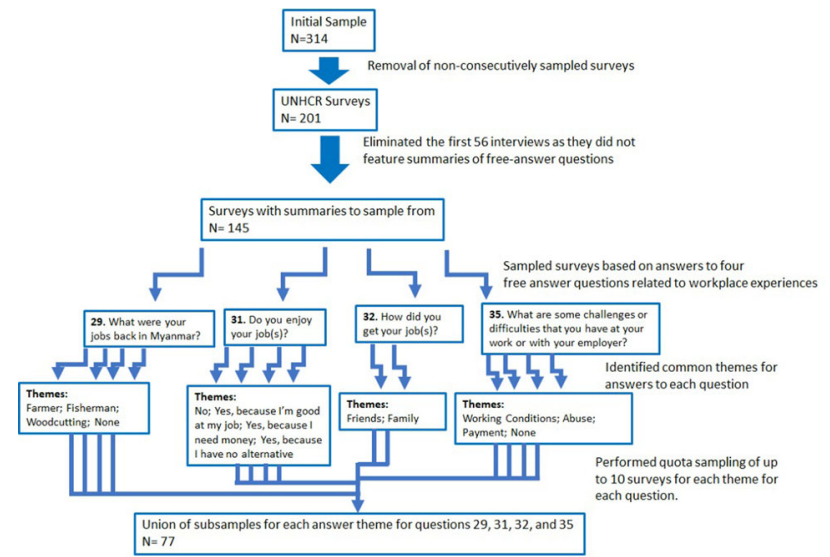

Fig. 9 Sampling framework for interviews chosen for thematic analysis. Sampling framework and findings of thematic analysis. 
Table 5 Dimensions and themes surrounding precarious employment.

\section{Theme(s)}

Dimension: employment insecurity

Late and lack of salary payments

Ambiguous work schedule and periods of employment

Dimension: lack of rights and protection Extreme heat when working outdoors

Lack of safety standards at workplace

Physical and verbal abuse by employers

Employers not responsible for workplace injuries

Harassment by law enforcement

Dirty and unhygienic living quarters provided onsite by employer

Dimension: income inadequacy

Inability to send sufficient remittances home

Inability to pay expenses for self and family

\section{Example(s)}

- "There are many types (of bosses). You have to work a long time for them to pay you. If they don't really know you, they won't pay you".

- "I used to have problems with my boss. I worked for a month and he still didn't pay me".

- "Sometimes we get paid less amount. If we get paid like that, we face problem".

- "The boss simply kicks me out from the job".

- "I'm done with my job. The boss said there is no more job. I've been looking for another job for a while".

- "I have problems. My employer doesn't pay me. And then he leaves, no work".

- "Construction I can make a lot of money, but it is very hot".

- "Sometimes, I can't take it anymore. Because we have to tolerate being in the sun. The sun is horrible. I can't take it anymore. For example, when we have to paint the roof. Painting the roof is very hot. It's hot on top of the roof, and also under the room. If it's like that, we are very happy. If we work inside, it is O.K. because we are not in the sun".

- "This is very hard. To work. If we have to cast the iron ourselves, so it feels...it is very heavy work. So, if it is carried by the crane (instead), it is normal for us".

- "If I don't work hard, the boss gets angry. Why aren't you working? They (the employer) gets angry and asks me what I'm doing here. They make a lot of noise".

- "They (the employer) gets angry at me a lot. Even if I make small mistakes, he gets very angry".

- "My work is dangerous because I work very high up. It's very dangerous...because I don't have anything. I don't have my employer. If anything happens, nobody will be responsible for me. I am responsible for myself".

- "Sometimes, police immigration came. Whether have (UNHCR card) or not, original or fake, they take them to detention center".

- "I don't have problems with my employers. But I have a lot of problems with immigration people".

- "Sometimes, the police came and check the (UNHCR) card".

- "I would really like to work without being bullied at the construction site. I have a lot of challenges because I don't have any documents".

- "I don't like (working in Malaysia). I can barely sleep...my room is too small. There are fleas. Cockroaches. A lot of them, I can't sleep".

- "I've been in Malaysia for more than 17 years. Even if I work very hard, they (the employer) doesn't give me money. I use the money to send home to my family, there, in the village, I have a mother and siblings. I send money there. Here, I pay rent. That's why I'm still not married. I don't have enough money. I want to be rich, I want to get money. I want to work more, so I can earn more".

- "If I had documents, I could support my family. Now, it is very difficult to support my family".

- "I have a large family and I am the only one who works. I can't do any other job. I look but there's nothing else".

- "Living in Malaysia...I don't have enough salary. I have a lot of family (members). Every month, my father has to be hospitalized. Again". working outdoors, lack of safety standards at workplace, physical and verbal abuse by employers, employers not being held accountable for workplace injuries, harassment by law enforcement, and dirty and unhygienic living quarters provided onsite by employers. Finally, under the dimension of income inadequacy, we found that some respondents faced an inability to send sufficient amount of remittances home or were unable to pay expenses for self and family. Examples from the data on each of these themes are displayed in Table 5.

\section{Conclusion}

In this study, we find that informal jobs offered in the construction sector in Peninsular Malaysia have provided the means of earning an income above poverty and minimum wage levels to Rohingya refugees. However, their employment and life remain precariousas seen in Section "Dimensions of precarious employment", their work life is characterized by horrible working conditions, physical abuse, and late and lack of salary payments. Cases of bribery are commonly heard among all respondents in order to avoid arrest and detention by the authorities, and this has resulted in arbitrary jailing and feelings of insecurity in their day-to-day lives. These security issues have exacerbated recently in times of the COVID-19 pandemic as the number of raids and forced detentions at jails and immigration centers have increased (Ahmed and Agencies, 2020; Latiff, 2020). Thus, if one considers an anti-reductionist, holistic approach to poverty that takes into account other non-economic factors and social exclusion, such as in Wagle (2002), Rohingya refugees are still impoverished, despite the fact that they have access to reasonably well-paying jobs.

The construction industry is a significant sector of the economy to Malaysia-in the first quarter of 2020, it contributed about $4.5 \%$ to the Malaysian gross domestic product (GDP) (Kamarulzaman, 2020). Although there are no formal figures on how many refugees are actually employed in the construction industry, given the prevalence of existing refugee social networks to obtain jobs in this sector, as presented in this study, we are able to conclude that the number is significant. This being, we would like to end our paper by 
urging the Malaysian government to legalize and protect all refugees who live in this country. It is incomprehensible that a segment of individuals who work so hard and face so much risk and precarity in their jobs towards the goal of bettering the country are treated so poorly and given no legal rights.

\section{Data availability}

The datasets generated and analyzed during the current study are available from the corresponding author on reasonable request.

Received: 29 April 2020; Accepted: 15 September 2020;

Published online: 08 October 2020

\section{Notes}

1 The PLI value of RM 980 was based on 2005 methodology and has been revised recently to RM 2208 in 2019 methodology.

2 The book suggests that Rohingya might descend from one of the earliest settlers in Arakan and many have adopted Islam by the eleventh century. A few other historical records cited in the book also present a substantial evidence supporting the presence of Rohingyas in Arakan prior to Burmese invasion in 1784.

3 Our dataset includes 36 observations without information on wages. Owing to the small sample size, we endeavor to include every observation possible, so we have predicted wages as a function of monthly income, which we also observe, and used those predicted values for the 36 missing wage observations. Generally, monthly income is a noisier measure as it requires respondents to calculate monthly wages based on weekly pay, which is itself variable. However, they are highly correlated with a Pearson's $r$ of 0.75 . We did not include these predicted wages in Table 3.

\section{References}

Adams RH, Page J (2005) Do international migration and remittances reduce poverty in developing countries? World Dev 33:1645-1669. https://doi.org/ 10.1016/j.worlddev.2005.05.004

Ahmed K, Agencies (2020) Malaysia cites Covid-19 for rounding up hundreds of migrants. The Guardian

Alba R, Nee V (1997) Rethinking assimilation theory for a new era of immigration. Int Migr Rev 31:826-874. https://doi.org/10.2307/2547416

Alhadjri A (2020) Minister: Rohingya refugees to be deported or resettled. MalaysiaKini

Amnesty International (2017) "Caged without a roof": Apartheid in Myanmar's Rakhine state. Amnesty International, London

Anyan F (2013) The influence of power shifts in data collection and analysis stages: a focus on qualitative research interview. Qual Rep 18:1-9

Arango J (2000) Explaining migration: a critical view. Int Soc Sci J 52:283-296. https://doi.org/10.1111/1468-2451.00259

Bailey L, İnanç G (2018) Access to higher education: refugees' stories from Malaysia, 1st edn. Routledge, London

Braun V, Clarke V (2006) Using thematic analysis in psychology. Qual Res Psychol 3:77-101. https://doi.org/10.1191/1478088706qp063oa

Briggs CL (2001) Interviewing, power/knowledge, and social inequality. In: Gubrium JF, Holstein JA (eds) Handbook of interview research: Context and methodology. SAGE Publications, pp. 911-922

Buscher D, Heller L (2010) Desperate lives: urban refugee women in Malaysia and Egypt. Forced Migr Rev 34:20-21

Castles S (2010) Understanding global migration: a social transformation perspective. J Ethn Migr Stud 36:1565-1586

Chimni BS (2004) From resettlement to involuntary repatriation: towards a critical history of durable solutions to refugee problems. Refug Surv Q 23:55-73. https://doi.org/10.1093/rsq/23.3.55

Chiswick BR (1999) Are immigrants favorably self-selected? Am Econ Rev 89:181-185

Chiswick BR, Miller PW (2001) A model of destination-language acquisition: application to male immigrants in Canada. Demography 38:391-409. https:// doi.org/10.2307/3088354

Chuah FLH, Tan ST, Yeo J, Legido-Quigley H (2018) The health needs and access barriers among refugees and asylum-seekers in Malaysia: a qualitative study. Int J Equity Health 17:120

Chuah FLH, Tan ST, Yeo J, Legido-Quigley H (2019) Health system responses to the health needs of refugees and asylum-seekers in malaysia: a qualitative study. Int J Environ Res Public Health 16:1-21

Construction Industry Development Board (2018) Construction industry review \& prospect 2018/2019. CIDB, Kuala Lumpur
Crisp J (2003) Refugees and global politics of asylum. Polit Q 74:75-87

Daly J, Kellehear A, Gliksman M (1997) The public health researcher: a methodological guide. Oxford University Press, Melbourne

de Haan A (1999) Livelihoods and poverty: The role of migration-a critical review of the migration literature. J Dev Stud 36:1-47. https://doi.org/10.1080/ 00220389908422619

de Haas H (2010) Migration and development: a theoretical perspective. Int Migr Rev 44:227-264. https://doi.org/10.1111/j.1747-7379.2009.00804.x

Elwood SA, Martin DG (2000) "Placing" interviews: location and scales of power in qualitative research. Prof Geogr 52:649-657. https://doi.org/10.1111/00330124.00253

Federal Government Gazette (2016) Minimum Wages Order 2016, Attorney General's Chambers of Malaysia

Ghazali MS, Tan PL, Rashid AA, Shariff SS (2020a) Developing a demographic, human capital values and economic profiling of Rohingya refugees workers in Malaysia. Environ-Behav Proc J 5:27-34

Ghazali MS, Tan PL, Shariff SS (2020b) Rohingya refugees employment readiness to Malaysian labour market: challenges and the way forward. Environ-Behav Proc J 5:35-41

Hagenaars A, de Vos K (1988) The definition and measurement of poverty. J Hum Resour 23:211-221

Hoffstaedter G, Perrodin L (2019) Life in Limbo: refugees in Malaysia. In: Lemière S (ed) Illusions of democracy. Amsterdam University Press, pp. 183-200

Huennekes J (2018) Emotional remittances in the transnational lives of Rohingya families living in Malaysia. J Refug Stud 31:353-370. https://doi.org/10.1093/ jrs/fey036

Ibrahim A (2016) The Rohingyas: inside Myanmar's Hidden Genocide. Hurst, London

Jacobsen K (2014) Livelihoods and forced migration. In: Fiddian-Qasmiyeh E Loescher G, Long K, Sigona N (eds) The Oxford Handbook of Refugee and Forced Migration Studies. Oxford University Press

Joffe H (2011) Thematic Analysis. In: Harper D, Thompson A (eds) Qualitative research methods in mental health and psychotherapy: a guide for students and practitioners. Wiley-Blackwell, Chichester, pp. 209-223

Kamarulzaman F (2020) Is the construction industry only for foreign workers? Malays Insight

Kaur A (2007) Refugees and refugee policy in Malaysia. UNEAC Asia Pap 18:77-90 Kothari U (2002) Chronic poverty and migration. Chronic Poverty Res Cent Work Pap, Institute for Development Policy and Management 16

Kreshpaj B, Orellana C, Burström B et al (2020) What is precarious employment? A systematic review of definitions and operationalizations from quantitative and qualitative studies. Scand J Work Environ Health 235-247. https://doi. org/10.5271/sjweh.3875

Kuhlman T (1991) The economic integration of refugees in developing countries: a research model. J Refug Stud 4(1):1-20

Kyaw NN (2017) Unpacking the presumed statelessness of Rohingyas. J Immigr Refug Stud 15:269-286. https://doi.org/10.1080/15562948.2017.1330981

Latiff R (2020) Malaysia seizes hundreds of migrants in latest lockdown raid Reuters

Lego J (2018) Making refugees (dis)appear: identifying refugees and asylum seekers in Thailand and Malaysia. Austrian J South-East Asian Stud 11:183-198

Letchamanan H (2013) Myanmar's Rohingya refugees in Malaysia: education and the way forward. J Int Comp Educ JICE 2(Issue 2DO):1014425005024

Lewa C (2009) North Arakan: an open prison for the Rohingya in Burma. Forced Migr Rev 32:11-13

Maguire M, Delahunt B (2017) Doing a thematic analysis: a practical, step-by-step guide for learning and teaching scholars. Irel J High Educ 9:3351-33514

Massey DS, Arango J, Hugo G et al. (1993) Theories of international migration: a review and appraisal. Popul Dev Rev 19:431-466. https://doi.org/10.2307/ 2938462

Medina L, Schneider F (2018) Shadow economies around the world: what did we learn over the last 20 years? IMF Work Pap 18, IMF

Milner J (2014) Protracted Refugee Situations. In: Fiddian-Qasmiyeh E, Loescher G, Long K, Sigona N (eds) The Oxford Handbook of Refugee and Forced Migration Studies. Oxford University Press

Mincer J (1974) Schooling, experience, and earnings. National Bureau of Economic Research, New York, NY

Nah AM (2010) Refugees and space in urban areas in Malaysia. Forced Migr Rev $34: 29-31$

Nord M (1998) Poor people on the move: county-to-county migration and the spatial concentration of poverty. J Reg Sci 38:329-351. https://doi.org/ $10.1111 / 1467-9787.00095$

Nungsari M, Flanders S, Chuah HY (2020) Refugee issues in Southeast Asia: narrowing the gaps between theory, policy, and reality. Refug Rev Emerg Issues Forced Migr 4:129-146

Quinlan M, Mayhew C, Bohle P (2001) The global expansion of precarious employment, work disorganization, and consequences for occupational health: a review of recent research. Int J Health Serv 31:335-414. https://doi. org/10.2190/607H-TTV0-QCN6-YLT4 
Remennick L (2003) Language acquisition as the main vehicle of social integration: Russian immigrants of the 1990s in Israel. Int J Sociol Lang 2003:83-105. https://doi.org/10.1515/ijsl.2003.057

Richmond AH (1993) Reactive migration: sociological perspectives on refugee movements. J Refug Stud 6:7-24

Sabates-Wheeler R, Sabates R, Castaldo A (2008) Tackling poverty-migration linkages: evidence from Ghana and Egypt. Soc Indic Res 87:307-328. https:// doi.org/10.1007/s11205-007-9154-y

Salim Y (2019) Livelihood sustainability among Rohingya refugees: a case study in Taman Senangin, Seberang Perai, Penang. Asia Proc Soc Sci 4:46-48

Schmillen AD, Tan ML, Abdur Rahman A et al. (2019) Breaking barriers: toward better economic opportunities for women in Malaysia. Word Bank Group, Washington, D.C

Skeldon R (2003) Migration and poverty. Johannesburg

Smith AA (2012) In search of survival and sanctuary in the city: refugees from Myanmar/Burma in Kuala Lumpur, Malaysia. International Rescue Committee, New York, NY

Stange G, Sakdapolrak P, Sasiwongsaroj K, Kourek M (2019) Forced migration in Southeast Asia-a brief overview of current research. Austrian J South-East Asian Stud 12:249-265

Sullivan D (2016) Still adrift: failure to protect Rohingya in Malaysia and Thailand. Refugees International

Syed Jaafar S (2020) Malaysia's absolute poverty rate at 5.6\%-chief statistician. Edge Mark.

Turton D (2003) Conceptualising forced migration. RSC Working Paper Series, vol. 12. pp. $1-17$

UNHCR (2016) Solutions for refugees. In: The 10-Point Plan 2016 Update. pp. 186-204. https://www.refworld.org/docid/583714a44.htm

UNHCR (2000) Flight from Indochina. In: The State of the World's Refugees: Fifty Years of Humanitarian Action. pp. 79-105

UNHCR (2020a) Global focus: UNHCR operations worldwide-Malaysia. http:// web.archive.org/web/20200310013136/http://reporting.unhcr.org/node/2532? $\mathrm{y}=2019 \% 23$ year. Accessed 11 Mar 2020

UNHCR (2019a) Global trends: forced displacement in 2018. UNHCR, Geneva

UNHCR (2019b) UNHCR fact sheet: Thailand. UNHCR, Geneva

UNHCR (2020b) Protracted refugee situations explained

UNHCR (2019c) Rohingya refugee response-Bangladesh: factsheet-protection

UNHCR Malaysia (2020) Figures at a glance in Malaysia. https://www.unhcr.org/ en-my/figures-at-a-glance-in-malaysia.html. Accessed 14 Aug 2020

United Nations (1946) Convention on the privileges and immunities of the United Nations. UN General Assembly

United Nations (2019) Detailed findings of the independent international factfinding mission on Myanmar. UN, Geneva

US Department of State (2019) Country reports on human rights practices for 2018 Burma. Bureau of Democracy, Human Rights and Labor, Washington, D.C
Wagle U (2002) Rethinking poverty: definition and measurement. Int Soc Sci J 54:155-165. https://doi.org/10.1111/1468-2451.00366

Wake C, Cheung T (2016) Livelihood strategies of Rohingya refugees in Malaysia: 'We want to live in dignity'. Humanitarian Policy Group, London

Warner D (1994) Voluntary repatriation and the meaning of return to home: a critique of liberal mathematics. J Refug Stud 7:160-174. https://doi.org/ $10.1093 /$ jrs/7.2-3.160

Yesmin S (2016) Policy towards Rohingya refugees: a comparative analysis of bangladesh, Malaysia and Thailand. J Asiat Soc Bangladesh Hum 61:71-100

\section{Acknowledgements}

We would like to thank our colleagues for their support, as well as the Durable Solutions and Registration Units at the United Nations High Commissioner of Refugees office in Kuala Lumpur, Malaysia, for their help in conducting the survey used in this paper. All mistakes are our own

\section{Competing interests}

The authors declare no competing interests.

\section{Additional information}

Correspondence and requests for materials should be addressed to M.N.

Reprints and permission information is available at http://www.nature.com/reprints

Publisher's note Springer Nature remains neutral with regard to jurisdictional claims in published maps and institutional affiliations.

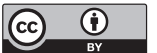

Open Access This article is licensed under a Creative Commons Attribution 4.0 International License, which permits use, sharing, adaptation, distribution and reproduction in any medium or format, as long as you give appropriate credit to the original author(s) and the source, provide a link to the Creative Commons license, and indicate if changes were made. The images or other third party material in this article are included in the article's Creative Commons license, unless indicated otherwise in a credit line to the material. If material is not included in the article's Creative Commons license and your intended use is not permitted by statutory regulation or exceeds the permitted use, you will need to obtain permission directly from the copyright holder. To view a copy of this license, visit http://creativecommons.org/ licenses/by/4.0/.

(C) The Author(s) 2020 